\title{
IMPLEMENTATION OF MEDIATION AND HAKAM IN DIVORCE CASE IN RELIGIOUS COURT
}

\author{
Salman \\ Doctoral Student of Islamic Law Study Program Concentration of Family Law \\ UIN Sunan Gunung Djati Postgraduate Program, Bandung, Indonesia \\ Email: salmantuankurajo09@gmail.com
}

\begin{abstract}
The resolution of divorce cases in the Religious Courts is still more dominant in the orientation of the litigation process than the non-litigation process, even though the spirit of suppressing the increase in the divorce rate from year to year is one of the missions that the Religious Courts want to achieve. Mediation institutions are actually established to encourage the realization of these ideals, but the results are still far from adequate. In fact, there are other ways in Islamic law that are believed to be effective in reducing the divorce rate, namely hakam. Unfortunately the rights have not been maximally applied by judges in resolving divorce cases at the Religious Courts
\end{abstract}

Keywords: hakam, mediation, divorce case, religious court

\section{A. INTRODUCTION}

It is almost certain that every household has difficult times when husband and wife experience conflict and tension. Basically this is something that is commonplace because husband and wife are a pair of people who come from different backgrounds, whether they are differences in age, family, education, the environment where they live before marriage, and so on. Therefore, it is not right for someone to hope that in their household there should never be any disputes and conflicts at all. The most important thing is that every Muslim knows the steps he must take when a conflict occurs.

Islam is a religion which with its perfection also has teachings on how to resolve conflicts that occur in marriage. In the process of resolving divorce cases at the Religious Courts, there is a stage where the judge orders the parties to participate in mediation, namely when both parties, the petitioner and the defendant (in a divorce case) and the plaintiff and defendant (in a divorce case) attend the trial. The situation becomes different if only the applicant or plaintiff is present. If during the examination of the case the panel of judges finds that the household conditions proposed by the applicant or plaintiff are not possible to maintain, then the case will be resolved in a verstek manner.

On the other hand, there is actually an institution taught in Islam to overcome this undesirable condition is "hakam." Regarding the Shari'a Hakam in the Koran we find it in the word of Allah in Surah An-Nisa 'verse 35,

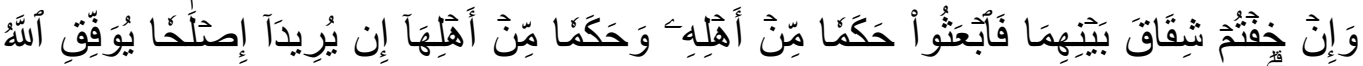

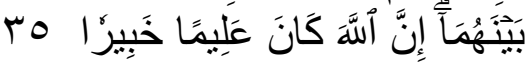


And if you are worried that there is a dispute between the two, then send a hakam from a male family and a hakam from a girl's family. If the two hakam intend to make improvements, surely Allah will give taufik to the husband and wife. Allah is All-Knowing, All-Knowing. (QS An-Nisa ': 35) In simple terms, hakam is usually defined as a peacemaker whose job it is to sort out a husband and wife who are in dispute. Hakam actually has a very strategic role and function in order to protect the household of the Muslims from falling into ruin and divorce. Hakam is a formulation that actually must be used by Muslims to make households have high immunity to various problems and conflicts that often lead to husband and wife separation. Hakam at the same time also shows how Islam educates its people to have a high level of concern for the affairs of their family and relatives where they will one day be involved to help solve problems that occur.

The reality is that many people misunderstand the meaning of respect for the independence of a household. The assumption that is widely circulated in our society is that if a husband and wife have married, from then on, it seems as if no one party may interfere in whatever problems the husband and wife face. This kind of understanding is clearly wrong and the teachings of hakam in Islam clearly show that it is permissible to intervene in a household if they are no longer able to solve their own problems. When those who are appointed as hakam are the families of each husband and wife, of course it can be understood that this figure is considered to be the person who knows the most about the ins and outs of household life. The understanding is that knowing within reasonable limits the household life conditions of a relative, neighbor or friend is something that is permissible and even recommended because there is a duty attached to someone if there is chaos in the household of a relative, neighbor or friend, namely ishlah, to reconcile. Because the sign meaning "hakaman min ahlihi wa hakaman min ahliha" in Surah An-Nisa "verse 35 is family or at least close people, which certainly means that they have certain knowledge and information about the conditions of the household that they wish to recite.

Actually there is another extreme faction, namely people who also do not understand the meaning of a family's independence so that even though someone is married, they still want to influence and even direct everything in their family life. Usually this happens to parents who are too possessive of their children so that even though their children are married, the parents still interfere and even intervene in many things and decisions that the child has to make.

\section{B. RESEARCH METHOD}

This study uses the library research method and content analysis in which the researcher conducts a search of various references both turats books, laws and regulations, journal articles and decisions related to this issue to then analyze these references in relation to the title of this research. Turats books in the form of books of fiqh and tafsir related to ishlah in general and hakam in particular provide initial references to the concepts and rules for settling divorce cases from an Islamic perspective. Furthermore, an analysis of the decisions on divorce cases is carried out to trace how many and the maximum number of judges in the Religious Courts use mediation as well as rights as an effort to resolve cases of marital disputes through peaceful means.

\section{RESULT AND DISCUSSION}

The rules regarding mediation can be found in the Supreme Court Regulation (Perma) Number 1 of 2016 concerning Mediation which regulates in great detail the mediation procedure in the Court. 
Meanwhile, the rules regarding rights can be found in Law Number 7 of 1989 concerning Religious Courts as amended by Law Number 3 of 2006 and Law Number 50 of 2009 Article 76 paragraph 2 which states that "the Court after hearing the statements of the witnesses regarding the nature of the quarrel between husband and wife can appoint one or more of the families of each party or other people to become judges, "however this provision is very inadequate to be maximally implemented by judges in the Religious Courts (PERMA No 1 Tahun 2016 Tentang Mediasi, 2016).

As stated in the preamble to Perma No.1 of 2016, mediation is a method of peaceful dispute resolution that is appropriate, effective and can open wider access for the parties to obtain a satisfactory and fair settlement. Mediation is also an instrument to increase public access to justice as well as the implementation of the simple, fast and low-cost principle of judicial administration. This is part of the Supreme Court bureaucratic reform which is oriented towards the creation of a great Indonesian judicial body.

With the existence of Perma No.1 of 2016, the application of mediation in court has indeed become more neat and structured. The provisions in the Perma also clearly provide guidance to judges, parties and mediators regarding the mediation process and procedure. The obligation to mediate is also regulated in such a way that if a judge does not order mediation in a case, while the parties to the case are making legal remedies, the judge at the appeal and cassation level must issue an interlocutory decision and order that the Court of first instance again summon the parties and order. mediation. In order to carry out mediation optimally, the Supreme Court also regularly annually conducts technical mediation training for judges so that more and more mediating judges become certified in each court of first instance (S. W. Sari, 2017).

Meanwhile, regarding rights, there is no sufficient technical rule as a guideline for judges. So far, the judges at the Religious Courts have only used figh references as a guideline for implementing hakam. This goes back to the belief that Islam is a religion that takes family and marriage matters very seriously. Various rules and methods are taught so that the household of believers can become a bridge to the happiness of the hereafter after first making it a means to carry out the duties of civilization in the world as much as possible. Hakam is one of the proofs of the perfect system contained in Islam in order to keep the family intact and as far as possible avoid the destruction in the form of divorce.

When interpreting the verse regarding hakam above, Shaykh Wahbah Az-Zuhaili explained that Allah ordered the judge, a husband and wife and their relatives, if there is a dispute, quarrel, even enmity between them, to send two peacemakers, one from the side. the husband and the other from the wife's side to try to reconcile after knowing completely what really happened between the husband and wife and knowing the cause of the dispute. If the desire in these peacemakers is really strong, then they also give up their intention and desire to improve the condition of this problematic household solely to seek the pleasure of Allah SWT, then Allah will surely open a path of goodness. Allah will also strengthen the mutual understanding between the husband and wife and will guide them to reunite and love and care for each other, as well as bring out tenderness between them. After that, Allah will send blessings for both of them (Az-Zuhaili, 2009 : 61-62).

Shaykh Wahbah Az-Zuhaili defines the word hakam in language as a just man who is able to reconcile (Az-Zuhaili, 2009 : 56). Furthermore, As-Sa'di explained that hakam were two men who were just, sensible, and knew what was happening between a husband and wife, and were also 
able to seek to unite or also divorce (Al-Sa'di, 2000). Sayyid Qutb explained that hakam are people who are let go by both men and women, who will meet in such a way in a calm atmosphere, far from subjectivity, away from personal feelings, also far from motives that can damage relationships. husband and wife, have a strong desire to protect the good name of both families, free themselves from the desire to beat and blame each other, and are very trusted to keep the family secret (AlQuthub, n.d.).

By reading the above verse and seeing how the scholars explain the meaning contained in this verse, we can understand how hakam does play a very important role. When a household is faced with a problem that they are no longer able to solve together, the judge is ordered to send a judge to help resolve the dispute that occurs between them. This also illustrates how Islam responds to the conditions of Muslim households in a way that is both realistic and ideal. Quarrel is something that is possible in every household. However, it does not mean that when an argument occurs, the arguing husband and wife will be allowed to just face the problems of their domestic life.

Hakam is present as a kind of "antidote" for the illness suffered by a disputing family. The presence of hakam, however, will open up greater opportunities for peace than if the husband and wife have to solve their problems alone. The presence of these two peacemakers brings a fresher atmosphere to the heat of the feud that occurs in the marriage.

According to Imam Asy-Syafi'i, the law of sending the hakam is obligatory, because this is a way to eliminate the tyranny that may occur in household life. This is also an obligation that is stressed on the judge to carry it out. Zahir, the text also shows that this is a commandment (Az-Zuhaili, 2009 :62).

In terms of whether the rights must be taken from the family of each party, then this is actually something that is recommended (not mandatory). Hakam may also be taken from someone other than close family. The urgency of the presence of the hakam is to explore the problems that occur in a husband and wife who are in conflict, seek peace, but also to appear as a witness if in fact there is injustice between them. These goals can be achieved both on the part of the family and from parties outside the family of the husband and wife. Even so, it is still prioritized to seek rights from the family because this will reduce the possibility of this household problem spreading to other parties. In addition, relatives are the ones who know the condition of their relatives the most and are the party with the greatest desire to reconcile a husband and wife who are in dispute. Hakam on the part of relatives is also relatively more capable of being objective, not taking sides with one of the husband and wife who are fighting on the one hand, while on the other hand is closest to the peace of mind to solve problems (Az-Zuhaili, 2009 : 62).

According to Imam Malik and Imam Al-Sya'bi which are the opinions of Ali bin Abi Talib and Ibn Abbas, the hakam has the authority to reunite a husband and wife, but also has the right to separate the two. This authority does not depend on the permission of the husband and wife. The two rights have the right to do anything as long as there is a benefit to it, either divorce, or asking the wife to pay a certain amount of money to break away from marriage (khulu ') (Az-Zuhaili, 2009 : 63).

The scholars of fiqh said, "If there is a dispute between husband and wife, it must be reconciled by the judge as an intermediary. The judge is tasked with examining the second case and preventing injustice. If the business continues and the dispute escalates, the judge can send someone who is 
trusted from the woman's family and from the male family to discuss and research the problem (AlMubarakfuri, $2013: 507$ ).

Shaykh Abu Umar bin Abdil Barr said that the scholars agreed that if there was a difference of opinion between the two rights, then the other opinion would not apply. The scholars also agreed that the decision of the two to reunite must be made even if the husband and wife did not delegate their affairs to both of them. However, scholars have different opinions on whether the judicial decision on divorce should also be implemented or not. It is narrated from the jumhur that the scholars stated that the opinion on divorce must also be implemented, even without submitting a representative (Al-Mubarakfuri, 2013 : 508).

These two hakam gathered to work on ishlah. If in a husband and wife there is a strong desire to make up, which is prevented by anger (as a result of an argument), then Hakam tries in such a way as to help them, and Allah will show and open a way for them (Al-Quthub, n.d. : 140). Actually, everyone who tries to clean it up, will be guided by Allah (Al-Thabrani, 2000).

Another meaning of the sentence "in yurida ishlahan yuwaffiqillahu bainahuma" is that if the two rights sent really have a strong desire to reconcile the arguing husband and wife, then Allah will guide them both to really earnestly seek all possible means and strategies to promote peace. Allah will also guide both of them to really carry out these peaceful efforts wholeheartedly, with sincerity and sincerity because the energy of sincerity and sincerity will be very important assets for the success of efforts to reconcile those who are at odds.

The existence of hakam is actually a more specific and technical form of ish teaching which is one of the main deeds in Islam. There are many verses and hadiths that talk about both the commandment and the virtue of ishlah (reconciling two people who are in dispute). Allah says,

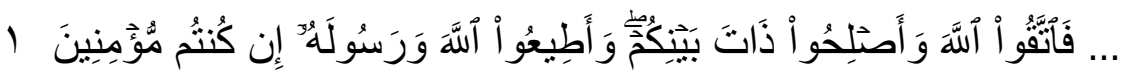

... fear Allah and improve relations among your neighbors; and be obedient to Allah and His Messenger if you are a believer. (QS Al-Anfal (8): 1)

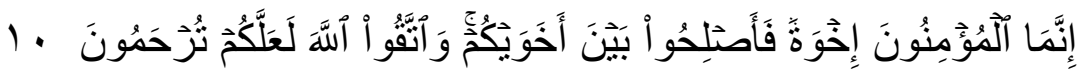

Believers are really brothers. Therefore reconcile (improve the relationship) between your two brothers and fear Allah, so that you may receive mercy. (QS Al-Hujurat (49): 10)

Rasulullah SAW also gave encouragement so that people of faith want to clean up those who are fighting. He said,

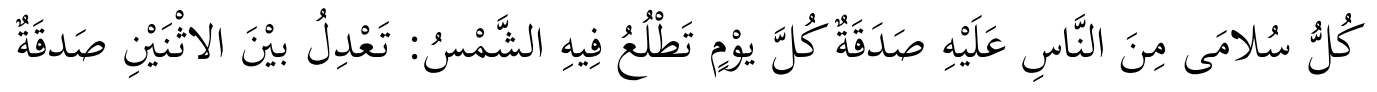

Every bone in the human body has a shadaqah, every day when the sun rises. Reconciling two people who are fighting is sadaqah ... (Bukhari, 1998) 


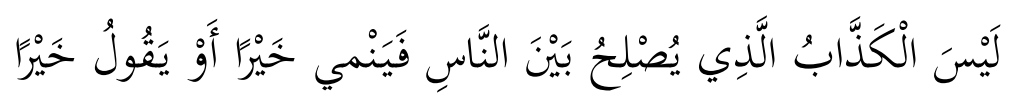

It is not called a liar, one who reconciles two people who are in dispute. (Al-Nawawi, 1981)

With all these arguments, mediation and rights that carry out the function of reconciling a husband and wife have carried out the orders of Allah and the Prophet. This is a charity of great value in the sight of Allah SWT. Of course, mediation and rights are only taken when a husband and wife are no longer able to solve the problems that occur between them by themselves.

The discussion on mediation institutions and rights in this paper, among other things, aims to provide an offer to the judicial system in Indonesia, which so far seems to have not used rights to its full potential. In the civil procedural law that has been in effect at the Religious Courts so far, efforts to reconcile the parties in a lawsuit are in the form of divorce cases, either in the form of contested divorce, namely divorce cases filed by the wife, or in the form of divorce, namely divorce cases filed by the husband. This has only been carried out through two methods, namely advisory at trial and mediation .

Advice at trials tends not to be maximal because it is related to the limited time available at trial, especially in courts that have a lot of cases. In fact, judges cannot really give maximum advice in court because they are limited by time. It is alleged that there are also some judges who no longer have high motivation to seriously carry out mediation. Some of the judges saw that the parties who had come to court were people who had experienced severe marital disputes with a very low probability of reconciliation so that there was no need to waste energy giving lengthy advice because it was believed that it would no longer have any effect. to the parties.

Even though it has become a mandatory procedure that must be followed by people who deal with religious courts, especially those filing cases for divorce, but mediators who are generally judges who serve in the religious courts who hear cases, also face obstacles in maximizing mediation, especially as well. due to time constraints. In courts with a relatively large number of cases, the judge must in such a way divide his time between carrying out the duties of the trial and its entire series, with other obligations including administering mediation.

This is where the mediation institutions and legal rights can actually be strategic solutions in helping the community to resolve marital dispute problems. By implementing mediation and using the Hakam as a peacemaker, of course there are many benefits that can be obtained. In addition to the relatively high potential for success in peace that can be considered relatively high, of course if there is peace between a married couple who initially wanted to divorce, it would reduce the number of cases that had to be decided by the court.

In order to optimize the implementation of hakam, in addition to the presence of technical rules on mediation such as the Supreme Court Regulation, it is hoped that other policies also function to increase the effectiveness of rights, such as providing counseling to the public regarding the importance of the role of rights in helping resolve marriage disputes. In this case, the Supreme Court could collaborate with the Ministry of Religion, especially BP4 (the Advisory Board for Marriage Development and Preservation) in providing enlightenment to the community regarding the importance of maintaining the integrity of the household, including providing an understanding 
of the existence of mediation and rights as a way to maintain a marriage. does not end in divorce (Sururie, 2012).

There are still many people who do not understand this kind of family law system as well as there are still very many people who do not have a solid understanding of how important it is to protect the household in order to survive in the face of various challenges and obstacles. Efforts to foster understanding in the midst of society about the urgency of rights and mediation can also be done by involving community organizations (mass organizations) and NGOs. The existence of large mass organizations such as Nahdlatul Ulama (NU), Muhammadiyah, Perti, Persis, Ikadi and others, which have a wide network to all corners of the country is actually a potential that can be utilized to implement the noble mission of maintaining the integrity of the citizen's household. . This of course is also the responsibility of the government as well as a forum for community contribution to the progress of the nation.

The reality shows that there is still a low level of awareness, attention and concern for the community towards the quality of household life. One of the most recent facts is the failure of the Family Resilience Bill (RUU) to serve as the DPR's initiative bill for the National Legislation Program (Prolegnas) because 5 out of 9 factions in the DPR did not approve of this bill being continued its discussion to become a law. The five factions are PDI Perjuangan, Golkar, Democrat, PKB, and Nasdem. Meanwhile, the proposers for the draft of the Family Resilience Law were the PKS, PAN, Gerindra and PPP factions. This is actually an indicator that efforts to raise awareness to pay serious attention to the sanctity of the marriage bond will still take a long time. However, all strategies and efforts, including through academic, research and research channels, must continue to be carried out (H. P. Sari, 2020).

In the draft of the Family Resilience Law, there are articles that are expected to help a married couple to maintain the integrity of their household if a problem occurs. In Article 25 paragraph (3), for example, it is stated that one of the obligations of a wife is to maintain the integrity of the family. Article 131 states that the community plays a role in family resilience. Furthermore, in Article 132 it is stated that the community can participate in providing advocacy in solving family problems, of course this includes family problems in the form of potential divorce as a result of conflicts that have occurred for a long time or have been protracted. This bill even includes regulations related to sexual deviance. Article 87 states that adults who experience sexual deviations are obliged to report to the body that handles family resilience for treatment and care. The proposers for this bill promised to make efforts again so that the regulations related to family resilience could be reincluded in the prolegnas. We hope that this bill can become a law as soon as possible and it is hoped that there will also be regulations related to efforts to prevent conflicts in the household, including efforts to reduce conflict so that it does not end in divorce. The existence of a law is of course an effective entry point for the existence of a special budget prepared by the state in order to strengthen one of the pillars of the integrity of the nation and state, namely the family..

\section{CONCLUSION}

From this research it is found that the implementation of mediation and rights in the Religious Courts is still not ideal. One thing that is ironic is the absence of binding technical rules related to the application of legal rights in the process of settling divorce cases. The existing regulations only provide alternatives to judges and do not provide instructions for maximum fulfillment. This study 
provides recommendations for the Supreme Court to issue technical rules that can serve as binding guidelines for judges in the Religious Courts so that the implementation of rights can be better..

\section{References}

Al-Mubarakfuri, S. (2013). Shahih Tafsir Ibnu Katsir. Pustaka Ibnu Katsir.

Al-Nawawi. (1981). Sahih Muslim bi Syarh al-Imam an-Nawawi: Vol. VII. Dar al-Fikr Araby.

Al-Quthub, S. (n.d.). Fi Zhilal al-Qur'an. Dar al-Tauhid wa al-Jihad.

Al-Sa'di, A. al-R. bin N. bin. (2000). Taisir al-Karim al-Rahman fi Tafsir Kalam al-Mannan. Muassasat al-Risalah.

Al-Thabrani, M. I. J. bin Y. bin K. bin G. al-A. A. J. (2000). Jami' al-Bayan 'an Ta'wil Ay al-Qur'an. Muassasat al-Risalah.

Az-Zuhaili, W. (2009). Al-Tafsir al-Munir fi al-'Aqidah wa al-Syari'ah wa al-Manhaj. Dar al-Fikr.

Bukhari, M. bin I. (1998). Shahih al-Bukhari. Baitul Afkar ad-Dauliyah.

PERMA No 1 Tahun 2016 Tentang Mediasi. (2016). https://www.pnsubang.go.id/index.php?id=1327

Sari, H. P. (2020). 3 Poin Dalam RUU Ketahanan Keluarga yang Tuai Kritik Halaman allKompas.com. https://nasional.kompas.com/read/2020/02/27/05582961/3-poin-dalam-ruuketahanan-keluarga-yang-tuai-kritik?page=all

Sari, S. W. (2017). MEDIASI DALAM PERATURAN MAHKAMAH AGUNG NOMOR 1 TAHUN 2016. Ahkam, 5(1).

Sururie, R. W. (2012). Implementasi mediasi dalam sistem peradilan agama. Ijtihad, Jurnal Wacana Hukum Islam Dan Kemanusiaan, 12(2). 